\title{
Importance of Moringa Oleifera for Wastewater Treatment: A Review
}

\author{
Md. Shahin Azad ${ }^{1}$, Mohd Sukri Hassan ${ }^{2}$ \\ ${ }^{1}$ Daffodil International University (DIU), Bangladesh \\ ${ }^{2}$ University Sains Islam Malaysia (USIM), Malaysia
}

\begin{abstract}
Moringa oleifera plant is easily available in Southeast Asian and African region. It has been used as medicine in many countries. It is rich in antibacterial, antimicrobial, and antioxidant compounds. The bark, root, and stem of the plant contains some important compounds. Such as alkaloids, phenols, and glycosides. That has an inhibitory effect against all gram-positive bacteria. Saponins, tannins, and steroids can be found in it seeds. Moringa oleifera root is extracted with ethanol, petroleum ether and aqueous. It has shown antifungals, and antibacterial activities. It has activities against three types of plant pathogenic fungi (Botrytis cinerea, Furasium oxysporum, Rhizoctonia solani). And also, actives against four types of bacteria (Bacillus cereus, Ralstonia solanacearum, Pesudomonas aeruginosa, Staphylococcus aureus). Moringa oleifera is inexpensive and effective sorbent for wastewater treatment. It is also eco-friendly nontoxic for removing pathogenic microbes from wastewater. Here, in this review paper we highlight to assess the effect of a different part of Moringa oleifera for removing pollutants from wastewater. It is showed that bark has an inhibitory effect against all grampositive bacteria, synthetic dyes as well as heavy metal removal and ethyl acetate extract of Moringa oleifera root showed high antibacterial activity against Pseudomonas aeruginosa. Hence it also proves that many parts of Moringa oleifera contains some compounds which are capable of acting as antimicrobial activity, dyes, and heavy metal removal activity from wastewater. The bark of $M$. oleifera is one of the most effective antimicrobial and heavy metal removal activity among the other part of Moringa oleifera for wastewater treatment.
\end{abstract}

\section{Introduction}

The basic requirement of a human body is fresh Water. By increasing population and industries as well as other factors are creating shortage of pure water. Now a days, the issue of wastewater is a concern for many developing countries. Thus, it needs to think about water purification using effective and inexpensive techniques and its reusability. Pure fresh water does not available appear in nature. If any water contains harmful substance that is called is water pollution. It is very important environmental issue. According to WHO (1997), any change in the physical, chemical and biological properties of water that has a dangerous effect on human beings and animals are called as 'water pollution'. It has various micro-biological agents such as bacteria, viruses and protozoa. It can also cause water pollution. It may cause various water borne diseases. Human and animal are taken in water for several purposes. But the water purity level is very crucial. For this reason, it can direct effect on health. The traditional wastewater treatment is used aluminium sulphate (alum) and calcium hypochlorite. But it's very expensive for developing country. Hence, they resort to sources of water such as streams, rivers and lakes. Wastewater comes from municipal, agricultural and industrial activity [1] as a by-product. Many pollutants especially inorganic in nature like heavy metals contaminate water ecosystems and create serious problems. Toxic metal compounds contaminate not only surface water but also ground water. Most of the heavy metals come from industry. Major toxic elements are lead $(\mathrm{Pb})$, copper $(\mathrm{Cu})$, nickel $(\mathrm{Ni})$, cadmium $(\mathrm{Cd})$, chromium $(\mathrm{Cr})$ etc. Wastewater is very harmful for river and human body [2].

Synthetic dye is used in many manufacturing industries for the coloring of products such as textile, paper, and paint. Around $50 \%$ of total dyes is released from textile industries. Now-a-days, synthetic dye controls most of the chemical industries. Methylene blue is a basic dye which is a heterocyclic aromatic compound. If consumed, it can cause irritation of mouth, throat with symptoms of jaundice in humans. Methylene blue dye enter into water system can cause human cancer of breast and skin.

Most of the water treatment processes are very costly in the global [3] [4].Therefore, now need to find natural alternatives that is cost effective and available. Moringa oleifera (MO) is one of these alternatives for wastewater treatment [5]. It has been found useful in nutrition, water purification, and industrial applications. Leaves and seeds of MO are very frequently used for water treatment. Moringa oleifera (MO) has no side effect. It is non-toxic and ecological material [6]. By oil extraction process, it is the natural coagulant. MOCR don't need further preparation for water purification process [7]. MO 
seed have coagulant properties [8]. Moringa oleifera cake residue (MOCR) can eliminate turbidity and also some bacteria and fungi [9] from wastewater. MO seed holds antibacterial properties [16] and coagulant properties [10]. Moringa oleifera is called drumstick or Ben oil tree. It is another name multipurpose plant for various functions. Moringa oleifera have valuable effect as a medicine, nutrition, water management, among others [11]. Leaves, fruits, roots of MO are used as vegetables [12], source of vitamins [13]. Moringa oleifera have several antimicrobial components [14-15]. Otherwise, [16] stated that presence of polyphenolic compounds Moringa plant extracts have antioxidant activities. Moringa oleifera seed has cyanobacteriacidal activity [17]. Moringa oleifera leaves have both macro- and micronutrients such as $\beta$ carotene, protein. It act as a natural antioxidants. Its leave hold hypolipidaemic and antiathersclerotic activities [18]. The seed also has excellent coagulation properties. Moringa oleifera pods have free radicals scavenging abilities [19]. The main aim of this study that the effect of different parts of Moringa oleifera are evaluated for removal of heavy metals, dyes and bacteria from wastewater.

\section{Properties of MO Precursor}

Moringa oleifera is the most important species of this family and multipurpose trees. It is available to the sub-Himalayan tracts of south East Asia [20]. Moringa oleifera [20] can be used as an absorbent and coagulation. The seeds also have antimicrobial activity. The seeds of Moringa oleifera are conventionally used as a natural coagulant. It has strong coagulating properties. Moringa oliefera (MO) successfully eliminated the heavy metal from wastewater. Generally, $1 \%$ of Moringa Oleifera is sufficient to purify of Wastewater [21].

The activated carbon of Moringa Oleifera has ability to remove anionic surfactants from wastewater. Even, a very high efficiency is observed in Moringa oleifera. So, it has presents a promising future as water treating agent. Polluted water is the derivative from agricultural and industrial activity. Now a days in the era of globalization, many water treatment methods have been invented. But most of them were required higher expenditure [22]. Aluminum sulfate is used as unadventurous chemical coagulant. But as an alternative natural coagulant, Moringa oleifera seeds can be used properly. It is increased demands for the wastewater treatment day by day. Due to its availability is limited because of population pressure. It is also economical option in the reuse of water. The key goal of adsorption studies to explore effectiveness and cheaply available of Moringa oleifera for reducing pollutants from environmental pollution. Various parts of Moringa oleifera $(\mathrm{MO})$ such as stem, bark, and roots have antimicrobial activities [23]. Moringa oleifera leaves possesses antimicrobial and antioxidant properties due to phytochemical compounds such as saponins, flavonoids, tannins and other phenolic compounds. The existence of pterygospermin compound which act as potential antibacterial and fungicidal effects. Moreover, polypeptide of adsorbents has bactericidal property against many pathogenic bacteria [24]. Moringa oleifera seed has cyano-bacteriacidal activity [25]. Moringa oleifera root ethyl acetate extract has sensitive to Staphylococcus aureus, Proteus mirabilis. Ethanol extract show activity against Pseudomonas aeruginosa, Staphylococcus aureu, Escherichia coli. Aqueous extract show activity against Pseudomonas aeruginosa, Staphylococcus aureus and E. coli. [26].

\section{Pretreatment, Potentiality, and Synthesis of Activated Carbon}

\subsection{Preparation of MO bark}

Moringa oleifera bark is collected from natural sources then it is washed with distilled water to remove dirt from its surface and dried in an oven at $110{ }^{\circ} \mathrm{C}$ for 13 hours. The Moringa oleifera bark is reduced into smaller particle sizes using blinder. The samples are then chemically activated using zinc chloride and sulfuric acid with ratio of 1:5 for 12 hours. Then the samples are dried in the oven at 110 ${ }^{\circ} \mathrm{C}$ for 12 hours. It is sieved at $400 \mu \mathrm{m}$. The precursor is placed in the furnace at $700{ }^{\circ} \mathrm{C}$ with heating rate of $10{ }^{\circ} \mathrm{C} / \mathrm{min}$ for $60 \mathrm{~min}$ [27]. It is cooled in normal temperature. This activated carbon samples are washed severally with distilled water. The washed samples are dried in oven at $110{ }^{\circ} \mathrm{C}$ for 15 hours. The activated carbon samples are kept in a polypropylene bottle to avoid moisture.

\subsection{Mo seeds preparation}

3.2.1. Oil extraction. Moringa oleifera seeds are collected from the plant. The dried seed kernels put in the oven at $40^{\circ} \mathrm{C}$. It is grounded to a fine powder of approximate size $400 \mu \mathrm{m}$ using sterile mortar and pestle. To achieve solublization of active ingredients in the seed. The soxhlet extraction method is used to extract the oil from MO [28]. Firstly, take about $10 \mathrm{~g}$ of MO seed powder then put into an extraction thimble. A round bottom flask is taken a $170 \mathrm{ml}$ of hexane solvent. After setting up the soxhlet apparatus, the hexane solvent heat for $45 \mathrm{~min}$ is run and the oil is extracted. After extraction, Moringa oleifera Cake residue (MOCR) is collected from the thimble. It is dried in an oven at $50^{\circ} \mathrm{C}$ for overnight. Once the oil is fully removed from the MO seed. There are two samples of MOCR use for water treatment. One of cake residue is called Hexane 
Freshly Prepared (HFP). Another the second sample is stored for six months. In water treatment to study the effect of storage time on the performance of the cake residue. It is called Hexane Long Storage (HLS). The presence of oil in the MO seed would affect the coagulation activity and antimicrobial effect [29]. For this reason, the oil is extracted from the seeds. The oil content in MO seed, the bad performance of the MOCR is occurred in water treatment process.

3.2.2 Stock solution preparation. The stock solution is prepared by adding the distilled water to MOCR. Using a magnetic stirrer, the suspension is vigorously shaken for 30 minutes. Then it is passed through filter paper (Whatman No. 1). Fresh solutions are prepared daily. It is kept refrigerated to prevent any ageing effects. Solutions are shaken vigorously before use. Different concentrations prepare in distilled water $(\mathrm{mg} / 5 \mathrm{ml})$ by dissolving 50 , 100 and $150 \mathrm{mg}$ of the seed powder to gain 10,000, 20,000 and $30,000 \mathrm{mg} / \mathrm{L}$ with percentage of $1 \%, 2 \%$ and $3 \%$, respectively.

\subsection{Moringa oleifera (Lam.) root preparation}

Moringa oleifera root is taken from natural plant. It is identified and authenticated by Botanical Survey.

3.3.1 Preparation of extraction. The plant material has to cut into small pieces. After that dry and ground to powder. Then about $500 \mathrm{~g}$ of powdered plant root extract with petroleum ether, ethanol, and aqueous [1:5]. At last extracts is filtered using filter paper and is evaporated for drying.

3.3.2 Microbial strains. Pure cultures of bacterial strains Pseudomonas aeruginosa, Staphylococcus aureus, Escherichia coli are obtained from the Department of Microbiology.

\section{Environmental Applications and Test of MO-Derived AC}

\subsection{Adsorption of Organic Pollutants}

There are many routes for disposing of organic pollutants like dyes into environment. Among those ways, textile industries are releasing huge amounts of toxic dyes. They are mixed with water. It can be threatened for human body and water system. Wastewater contain large amount of chemicals with synthetic dyes like methylene blue and pigments into environment, causing health problem concern. Some methods can be used for the treatment of organic pollutants. Among them, adsorption process using activated carbon is the best effective process for the removing organic contaminants from wastewater. The good results were obtained using adsorbents of Moringa oleifera to the removal of methylene blue dye [30]. The activated carbon of Moringa oleifera has many advantages including cost effectiveness and forms of mesoporous activated carbon.

\subsection{Adsorption of Heavy Metals}

Many heavy metals (HMs) with synthetic dyes produced industries are contained in wastewater, which have bad effects on humans and environments [31]. The main sources of toxic metals are verities industrial activities. Heavy metals are the most dangerous pollutants in the environments. According to the World Health Organization (WHO), the most toxic metals are cadmium, chromium, copper, lead, mercury, and nickel [32]. Activated carbon is huge used for toxic metal removal [33]. The binds of HM ions from wastewater are an adsorption method through electrostatic interactions [34]. There are some factors such as surface area and porosity, the solution $\mathrm{pH}$ and the point of zero charges of the surface, the surface functionality, and the size of adsorbing species govern the adsorption of HMs in AC.

\subsection{Adsorption of Inorganic Anions}

Inorganic anions are another group of pollutants in wastewater which are known to be toxic and carcinogenic. The presence of these anions in ground and surface waters has resulted in severe contamination, and they can cause adverse health effects. For example, phosphate in surface water and groundwater caused water quality problems. Fluoride poses a serious threat to public health and causes dental and skeletal fluorosis. WHO limits the fluoride concentration in groundwater to $1.5 \mathrm{mg} / \mathrm{L}$ [35]. Also, water pollution occurs due to excessive discharge of nitrate $\left(\mathrm{NO}_{3}{ }^{-}\right)$and bromide $\left(\mathrm{Br}^{-}\right)$in the environment [36-38]. Maximum limits of $50 \mathrm{mg} / \mathrm{L} \mathrm{NO}_{3}^{-}$for adult and $15 \mathrm{mg} / \mathrm{L} \mathrm{NO}_{3}^{-}$for infant drinking water are permitted [39].

\subsection{Adsorption of Bacteria}

The effect of dosage of activated carbon on bacteria were studied [30]. The stem bark of agricultural products can show antibacterial activities. The number of cells for both bacteria is decreased while using adsorbents. The efficacy of activated carbon on bacteria is dose dependent. The removal percentage of E.coli are obtained as $29.3 \%, 62.7 \%$ and $87.8 \%$ respectively using 1,3,5 mg activated carbon of Moringa oleifera at 37 degree for 1 hour. On the other hand, the removal percentage of Pseudomonas aeruginosa incubated with $1,3,5 \mathrm{mg}$ adsorbents are obtained 
as $59.8 \%, 74.1 \%$ and $90 \%$ respectively. E. coli is decreased as $98 \%$ and Pseudomonas is reduced as $96 \%$ using $10 \mathrm{mg}$ of adsorbent [30].

\subsection{Adsorption Mechanism of Activated Carbon}

There are some important factors for heavy metals, dyes and bacteria adsorption onto activated carbon, such as (i) Van der Waals attraction, (ii) hydrogen bonding (iii) pore filling and (iv) ion exchange [30]. On the other hands, the $\pi-\pi$ and $\sigma-\pi$ interactions depends on the structure of $\mathrm{MB}$ and adsorbents. These types of interaction are less important for adsorption of MB. The surface area of adsorbents can influence the Van der Waals attraction. Generally produced activated carbon contains high surface area and pore volume. That is why pore filling happens easily in porous activated carbon. Van der Waals forces and pore filling are important adsorption mechanisms. But methylene blue (C16H18ClN3S) has high molecular weight which could not easily enter the inner pores of adsorbents. However, the nitrogen atom of methylene blue can participate in bonding as a hydrogen bond with oxygen atoms on outer surface of adsorbents. Furthermore, Methylene blue could bind with acidic groups of adsorbents by ion exchange methods. The hydrogen bonding and ion exchange methods are very vital adsorption mechanisms for methylene blue. This type of adsorption process is correlated with oxygen containing functional groups. Generally, methylene blue adsorption onto activated carbon is occurred by active site on the surface, film diffusion and adsorption into the interior pore of the adsorbents and monolayer build-up of adsorbate. Film diffusion is better than inter-particle diffusion in this process. There are several factors which affect the adsorption process.

\subsection{Antibacterial tests}

About the cells $\left(1.15 \times 10^{7}\right)$ of E. coli and $\left(1.73 \times 10^{7}\right)$ of Pseudomonas aeruginosa are mixed with activated carbon (1, 3, 5, 10mg) of Moringa oleifera respectively. These mixtures are incubated at $37^{\circ} \mathrm{C}$ with agitation for 1 hour and after then centrifuged for $5 \mathrm{~min}$. After separating, it is then placed onto nutrient agar of disks to determine the number of bacteria. All disks are placed into the incubator at $37^{\circ} \mathrm{C}$ for 24 hours. After incubation, the number of bacteria are counted using magnifying glass [30].

\subsection{Heavy metal removal measurement}

The heavy metal removal test is done by using a Atomic Absorption Spectrometer (AAS). A series of calibration solution of heavy metals such as copper, and cadmium are prepared from standard stock solution $(1000 \mathrm{mg} / \mathrm{L})$. Each of the metal solution is prepared with 4 different concentrations of 1 to 5 ppm [27].

\section{Future Prospects}

Different methods have been implemented to prepare activated carbon from different part of $\mathrm{MO}$ for the adsorption of different organic pollutants, heavy metals, and micro-organism from aqueous solutions. There are several concerns that need to be addressed to utilize low-cost AC for removing pollutants from wastewater.

Future research should be focused on the following:

- Regeneration of used AC and proper disposal systems should be improved.

- There are needed to test the AC of MO under real field conditions.

- The mechanism of pollutant removal using MOderived AC should be given more focus to obtain a clear understanding.

- The commercial production system should be developed.

- A proper new system for regeneration needs to be advanced.

\section{Conclusion}

The different part of Moringa oleifera show good removal activity against heavy metals, dyes and bacteria. As bioactive compounds from Moringa oleifera bark and root could assist as natural antimicrobials source. MOCR is a good coagulant for wastewater treatment. It can successfully reduce bacterial growth for wastewater samples. Moringa oleifera have more activities against bacterial and fungal growth. These results can be attributed for phytochemical compounds in these extracts. Aqueous and ethanol seed extracts of Moringa oleifera had more activities against bacterial and fungal growth. The seeds of Moringa oleifera can be used as an antibacterial and antifungal agent against the tested micro-organisms. Increasing population, economic activity and industrialization have demand for fresh water. Water resources are threatened not only by lowly management but also by environmental degradation. Moringa oleifera are shown auspicious result in the clarification of wastewater. The bark of Moringa oleifera can successfully remove the heavy metals, methylene blue, E.coli and P. aeruginosa from wastewater. Overall, $1 \%$ of (MOCR) is enough to remove heavy metals from Wastewater. Moringa oleifera bark has inhibitory influence against gram positive bacteria. The bark of Moringa oleifera are one of the most 
effective antimicrobial activity amongst the other part of Moringa oleifera for wastewater treatment. Moreover, the mechanism of bacteria removal is not yet clear. Hence, further research is needed. So, the verities part of Moringa oleifera can be used as an vital adsorbents for wastewater treatment.

\section{References}

[1] T.G. Ellis, "Chemistry of Wastewater", Environment and Ecological Chemistry, (2004), 2.

[2] M.G. Arafat, and S.O. Mohamed, "Preliminary Study on Efficacy of Leaves, Seeds and Bark Extracts of Moringa oleifera in Reducing Bacterial load in Water", International Journal of Advanced Research, . (2013), 1, 124-130.

[3] R. Joshua, and V. Vasu, "Characteristics of Stored Rain Water and Its Treatment Technology Using Moringa Seed", International Journal of Life Science and Pharma Reviews, (2013), 2, 155-174.

[4] K.A. Ghebremichel., K.R. Gunaratna, H. Henriksson, H. Brumer, and G. Dalhammar, "A Simple Purification Activity Assay of the Coagulant Protein from Moringa oleifera Seed", Water Research, (2005), 39, 2338-2344.

[5] M. Lea, "Bioremediation of Turbid Surface Water Using Seed Extract from Moringa oleifera Lam. (Drumstick) Tree", Current Protocols in Microbiology, (2010), 16, 1G.2.1-1G.2.14. http://dx.doi.org/10.1002/9780 471729259.mc01g02s16

[6] J.H.O., Onyuka, R. Kakai, P.F. Arama, and A.V.O. Ofulla, "Comparison of Antimicrobial Activities of Brine Salting, Chlorinated Solution and Moringa oleifera Plant Extracts in Fish from Lake Victoria Basin of Kenya", African Journal of Food, Agricultural, Nutrition and Development, (2013), 13, 7772-7788.

[7] E. Arnoldsson, M. Bergman, N. Matsinhe, and M.K. Persson, "Assessment of Drinking Water Treatment by Using Moringa oleifera Natural Coagulant", Vattern, (2008), 64, 137-150.

[8] N. Vikashni, Matakite, M., Kanayathu, K. and Subramanium, S. (2012) Water Purification Using Moringa oleifera and Other Locally Available Seeds in Fiji for Heavy Metal Removal. International Journal of Applied Science and Technology, 2, 125-129.

[9] A.P. Meneghel, Jr. C.G. Affonso, R. Fernanda, D.C. Douglas, C.A. Lindino, and L. Strey, "Biosorption of Cadmium from Water Using Moringa (Moringa oleifera Lam.) Seeds", Water, Air, \& Soil Pollution, (2013), 224,1383 .

[10] P.P. Ndibewu, R.L. Mnisi, S.N. Mokgalaka, and R.I. McCrindle, "Heavy Metal Removal in Aqueous System Using Moringa oleifera: A Review", Journal of Material Science and Engineering, (2011), 6B, 843-853.
[11] RN. Bennette, FA. Mellon, N. Foidl, JH. Pratt, MS. Dupont , L. Perkins, PA. Kroon, J. Agric. food chem., (2003), 57:3546-3553

[12] Siddhuraju P, Becker K, J .Agric. Food Chem.2003, 51:2144-2155.

[13] PS. Lalida, R. Thidarat, SL. Vannajan, D. Srisulak, J. of Med. and Bioengine. (2013),(2):163-167.

[14] F. Fozia, R. Meenu, T. Avinash, K. Abdul Arif, F. Shahila, J. of Med. plants Res., (2012), 6(27): 4368-4374. doi:10.5897/JMPR12.279.

[15] SS. Bako, JU. Okere, AC. Etonihu, Y. Mohammed, OA. Olanisakin, BO. Atolaiye, PC. Mau, Raw materials research and development council: Moringa - A national crop for economic growth and development, (2010), 107114.

[16] JA Torres-Castillo, SR. Sinagawa-García, GC. Martínez-Ávila, AB. López-Flores, EL. SánchezGonzález, VE. Aguirre-Arzola, RI. Torres-Acosta, E. Olivares-Sáenz, E. Osorio-Hernández, A Gutiérrez-Does, Inter. J. of Exp. Bot., (2013), 82:193-202.

[17] M. Lurling and W. Beekman, "Anti-cyanobacterial activity of Moringa oleifera seeds", Journal. Appl. Phycol, 22(4), 2010, 503-510.

[18] C. Pilaipark, K. Panya, S. Yupin, P. Srichan, NP. Morales, P. Laddawal R.Piyanee ,S. Supath , and PS.Klaiupsorn, "The in vitro and ex vivo antioxidant properties, hypolipidemic and antiatheroscleortic activities of water extract of Moringa oleifera (Lam.) Leaves", Journal of Ethanopharmacology, 116, (2008), 439-446.

[19] S. Kumar, D. Kumar, N. Singh and BD. Vasisht, "In vitro Free Radical Scavenging and antioxidant activity of Moringa oleifera pods", Journal of Herbal Medicine and Toxicology, 1(2), 2007, 17-22.

[20] K. Prabhu, K. Murugan, A. Nareshkumar, N. Ramasubramanian, \& S. Bragadeeswaran, "Larvicidal and repellent potential of Moringa oleifera against malarial vector, Anopheles stephensi Liston (Insecta: Diptera: Culicidae)", Asian Pacific Journal of Tropical Biomedicine, (2011),1(2), 124-129.

[21] N. A. Eman, C. S. Tan, \& E. A. Makky, "Impact of \&lt;i\&gt;Moringa oleifera\&lt;/i\&gt; Cake Residue Application on Waste Water Treatment: A Case Study", Journal of Water Resource and Protection, (2014), 06(07), 677-687.

[22] R Joshua, \& V. Vasu, "Characteristics of Stored Rain Water and Its Treatment Technology", Int. J. LifeSc. Bt \& Pharm. Res., (2013), 2(1), 2250-3137.

[23] C. T. Lockett, C. C. Calvert, \& L. E Grivetti, "Energy and micronutrient composition of dietary and medicinal wild plants consumed during drought. Study of rural Fulani, Northeastern Nigeria", International Journal of Food Sciences and Nutrition, (2000), 51(3), 195-208. 
[24] M. Lürling, \& W. Beekman, "Anti-cyanobacterial activity of Moringa oleifera seeds", Journal of Applied Phycology, (2010), 22(4), 503-510.

[25] P. Chumark, P. Khunawat, Y. Sanvarinda, S. Phornchirasilp, N. P Morales, L. Phivthong-ngam, P. Ratanachamnong, S. Srisawat, \& K Pongrapeeporn, S.upsorn "The in vitro and ex vivo antioxidant properties, hypolipidaemic and antiatherosclerotic activities of water extract of Moringa oleifera Lam. Leaves", Journal of Ethnopharmacology, (2008), 116(3), 439-446.

[26] A. Raj, A. Gopalakrishnan, S. Yadav, \& S. Dorairaj, "Antimicrobial activity of Moringa oleifera (Lam.) root extract", Journal of Pharmacy Research, (2011), 4(5), $1426-1430$.

[27] M.S. Azad, M.S. Hassan, M. Shahinuzzaman \& S. Azhari, "Efficiently removal of copper and cadmium from wastewater using activated carbon produced from moringa oleifera", International Journal of Engineering Research \& Technology, (2020), 9, 695-706.

[28] E.N. Ali, S.A. Muyibi, H.M. Salleh, Z. Alam Md., and M.R.M. Salleh, "Production of Natural Coagulant from Moringa oleifera Seed for Application in Treatment of Low Turbidity Water", Journal of Water Resources and Protection, (2010) , 2,259-266.

[29] B. Garcia-Fayos., J.M. Arnal, G. Verdu, and A. Sauri, "Study of Moringa oleifera oil Extraction and Its Influence in Primary Coagulant Activity for Drinking Water Treatment", International Conference on Food Innovation, (2010).

[30] M.S. Azad, S. Azhari \& M.S. Hassan, "Removal of Methylene blue, Escherichia coli and Pseudomonus aeruginosa by Adsorption Process of Activated Carbon Produced from Moringa oleifera Bark", Malysian Journal of Science, Health \& Technology, (2020), 7, 29-39.

[31] I.H. Ali, M.K. Al Mesfer, M.I. Khan, M. Danish, M.M. Alghamdi, "Exploring Adsorption Process of Lead (II) and Chromium (VI) Ions from Aqueous Solutions on Acid Activated Carbon Prepared from Juniperus procera Leaves", Processes (2019), 7, 217.

[32] Water, S. World Health Organization. Guidelines for Drinking-Water Quality [Electronic Resource]: Incorporating First Addendum; Recommendations; WHO Library Cataloguing Data: Geneva, Switzerland, (2006), Volume 1.

[33] L. Khezami, R. Capart, "Removal of chromium(VI) from aqueous solution by activated carbons: Kinetic and equilibrium studies”, J. Hazard. Mater. (2005), 123, $223-$ 231.

[34] V. López-Ramón, C. Moreno-Castilla, J. RiveraUtrilla, L.R. Radovic, "Ionic strength effects in aqueous phase adsorption of metal ions on activated carbons. Carbon", (2003), 41, 2020-2022.

[35] F. Bailey, J. Chilton, E. Dahi, L. Fewtrell, Y. Magara, Fluoride in Drinking Water; World Health Organization: Geneva, Switzerland, 2006.
[36] M. Arauzo, "Vulnerability of groundwater resources to nitrate pollution: A simple and effective procedure for delimiting Nitrate Vulnerable Zones", Sci. Total Environ,( 2017), 575, 799-812.

[37] M.J. McGuire, J.L. McLain, A. Obolensky, Information Collection Rule Data Analysis; American Water Works Association(AWWA) Foundation and AWWA: Denver, CO, USA, 2003.

[38] S.W. Krasner, M.J. McGuire, J.G. Jacangelo, N.L. Patania, K.M. Reagan, E.M. Aieta, "The Occurrence of Disinfection By-products in US Drinking Water. J. Am. Water Work. Assoc. (1989), 81, 41-53.

[39] M.H. Ward, R.R. Jones, J.D. Brender, T.M. De Kok, P.J. Weyer, B.T. Nolan, C.M. Villanueva, S.G. Van Breda, "Drinking water nitrate and human health: An updated review", Int. J. Environ. Res. Public Health (2018),15,1557.

\section{Acknowledgments}

The authors are grateful to the University Sains Islam Malaysia (USIM) for providing in terms of e-resources, while conducting this review. They also acknowledge the support provided by FST faculty of USIM. 